\title{
Three new species of benthonic Harpacticoida (Copepoda, Crustacea) from Sáo Sebastiáo Channel
}

Tagea Björnberg

Center for Marine Biology of University of São Paulo (CEBIMar/USP), Rodovia Manoel Hypólito do Rego, km. 131,5, São Sebastião, SP, Brazil. E-mail: bjornber@usp.br

\begin{abstract}
Three benthonic Harpacticoida (Crustacea) new to science were collected in the São Sebastião Channel region (SE Coast of Brazil): Rhizotrix virginiae n.sp. (Rhizotrichidae), Galapalaophonte alvaroi n. sp. (Laophontidae) and Laophontisochra terueae n.sp. (Nannopodidae). Though similar to described species from the NW Atlantic benthos, the Caribbean region and the Patagonian continental slope, they differ in details, such as number of leg segments and/or setae, ornaments, etc. and are here described for the first time.
\end{abstract}

Key words: Harpacticoid copepods, marine benthos, SE coastal Brazilian littoral

\section{INTRODUCTION}

The taxonomy of the infauna harpacticoids of the littoral region of the Channel of São Sebastiâo region, Southern Western Atlantic, has received little attention until recently (Alvarez, 1986; Björnberg and Kihara, 2013). Kihara (2003) listed all literature about the species of Brazilian benthonic harpacticoids and added many new data of her own research. This paper gives some more information on the subject.

Scientists interested in the research of the Brazilian marine infauna have been collecting bottom samples in the São Sebastiáo Channel and kindly handed me the copepods among which, some new species. Three are the object of the present study.

\section{Material and Methods}

Collections were made with bottom samplers or manually with plastic cups. Specimens were separated from the samples, fixed in formalin $4 \%$, cleared with lactic acid and mounted on slides with a drop of glycerine. They were then drawn with the help of a microscope provided with a camera lucida. Details were observed with the use of a Leitz photomicroscope.

\section{Results And Discussion \\ Family Rhizothricidae Por, 1986 Genus Rhizothrix Sars, 1909 Rhizothrix virginiae n. sp.}

(Figs. 1-3)

Material examined. Holotype: one adult female, $0.480 \mathrm{~mm}$ long, from rostrum to end of furca (MZUSP-30280). Paratypes: two females, badly preserved, in the CEBIMar collection (access \# 9). Type locality: Barequeçaba beach near to a rocky outcrop, Itaçucê (4526' 68” W - 23 50'00” S); sandy bottom; water depth $5 \mathrm{~m}$.

Description. (Fig. 1A, B, C) Body cylindrical, slightly depressed dorsoventrally, covered with minute setules and ornamented with rows of setules; posterior margins of somites with fringe of longer setules. Rostrum elaborate, protuberant, bifid, protruding frontally and covered by a crown of setules, slightly defined dorsally and bearing a pair of small frontal rostral sensilla. Labrum, half circle shaped, covered by minute setules. Posteriorly to labrum another protuberance also densely covered by minute setules. Caudal rami slightly longer than wide bearing two 


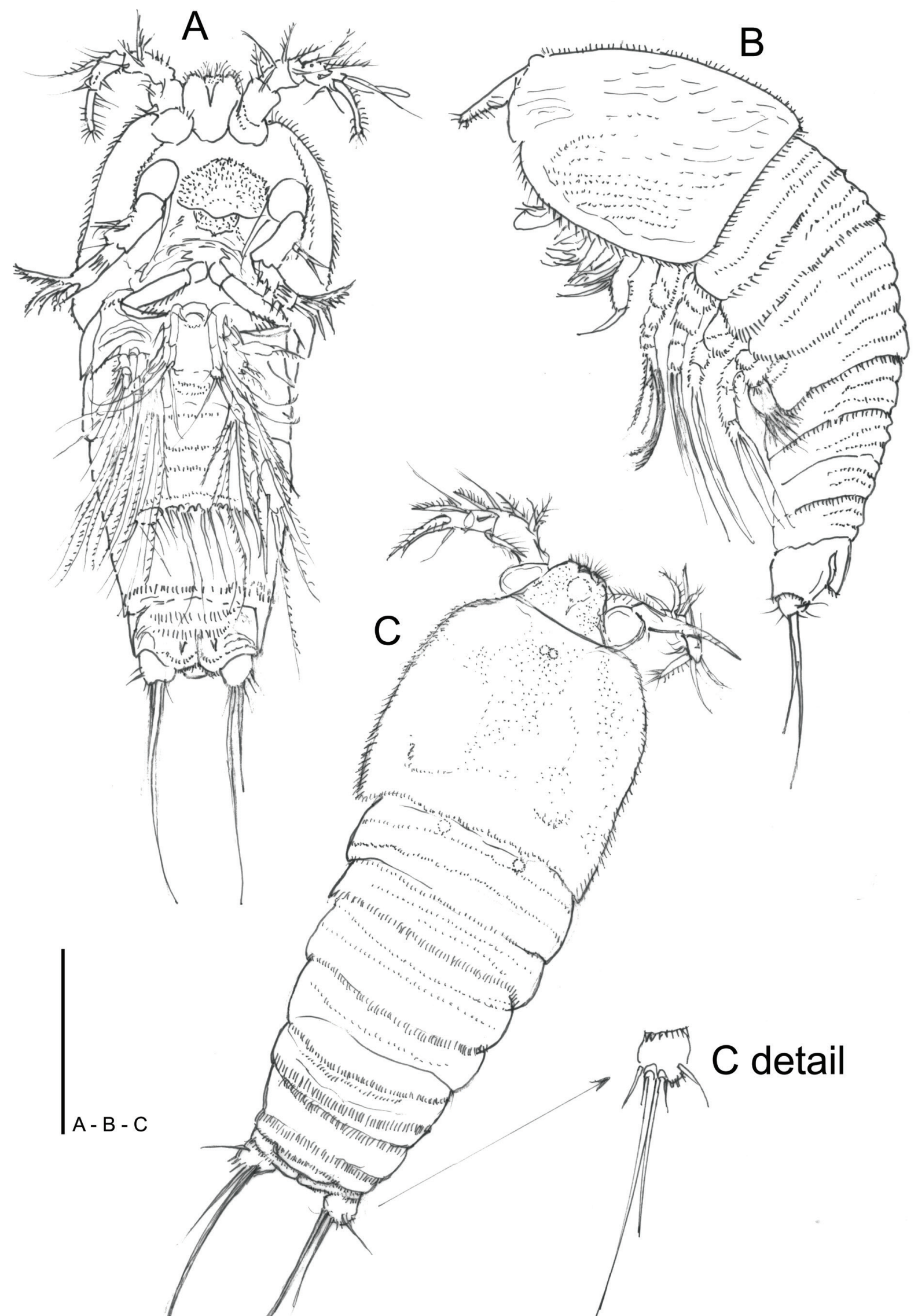

Figure 1. Rhizothrix virginiae n. sp. Female: (A) habitus, ventral; (B) lateral, antennules and antennae not represented; (C) habitus, dorsal. Scale bars $=0.10 \mathrm{~mm}$; scale bars of appendages $=50 \mu \mathrm{m}$ 
longer terminal setae, flanked by an inner and an outer very thin small seta; dorsally (Fig. 1C) a longer articulated small seta and laterally two marginal small setae. The anal operculum is small and wide, fringed posteriorly by a row of minute setules. Antennule (Fig. 2A) foursegmented: first segment with rows of spinules and 1 seta; on second, four setae; on third, 4 very spinulous and 3 glabrous setae, also an aesthetasc, last segment bearing 2 glabrous setules, a small pinnate seta and a strong terminal spinulous spine. Antenna: (Fig. 2B) exopod three-segmented with five spinules (one on each of the proximal two segments and three on the distalmost), endopod bearing a row of small, thin setules on dorsal face, three subterminaly marginal thin spines, distally three very strong spinulous spines, three less strong geniculate setae, and one long thick seta with a row of marginal spines. Mandible (Fig. 2C): coxa with cutting edge bearing about four blunt teeth, a small seta, rows of setules and a marginal hump; basis two-segmented, with two bipinnate setae, bearing the onesegmented endopod with 4 setae and the exopod represented by a pinnate seta. Maxillule: (Fig. 2D) strong with rectangular praecoxa, ornamented with minute setules, and arthrite with four terminal elements, coxa with two and basis with about seven setae. Maxilla (Fig. 2E) with syncoxa bearing two endites, basis with long pointed seta with lateral spine and a row of marginal setules, endopod and exopod formed by two setae. Maxilliped (Fig. 3A) two-segmented, covered with spinules, with a strong terminal claw and thin seta. P1-P4 (Fig. 3) biramous, with three-segmented exopods and two-segmented endopods, and very long setae. P1 (Fig. 3B) with wide coxa, protruding towards outer side, basis bearing one outer seta and a spine inserted on the anterior surface, exopod three-segmented with rows of setules, first and second segments with one outer, strongly spinulous seta; third segment with 4 marginal setae, of which two very long, terminally pinnate. Endopod two-segmented, longer than exopod, with inner very delicate setules, second segment bearing lateral setules, an inner small pinnate seta, and two terminal long thin setae distally pinnate. P2 (Fig. 3C) with coxa not protruding as in $\mathrm{P} 1$; basis with outer bipinnate seta; first and second exopod segments with one outer bipinnate seta each and rows of setules; third exopod segment bearing two terminal setae and two outer. P2 endopod two-segmented with a small, outer spinule on first segment and second segment with three pinnate terminal setae. P3 (Fig. 3D) as in P2. P4 (Fig. 3E) smaller than P3, coxa and basis as in P3, first and second exopod segments with a long outer pinnate seta each; third segment with four distal setae; endopod two-segmented with three terminal long setae. P5 (Fig. 3F) with coalescent basis, endopod and exopod. Basis of both fifth legs more or less coalescent bearing left and right outer setae; exopod, not distinctly separated from baseoendopod with five setae; endopod with four long bipinnate setae, the first pair separated from the next by an indentation on the margin of the basis, and separated from the next P5 leg by a stronger indentation. There is a lot of variation in the number of setae.

Etymology. The name of the species is given in thanks for the great help offered during this and other publications by Virginia Castilho, chief librarian of the Center of Marine Biology.

Type locality. São Sebastião Channel (Itaçucê, Barequeçaba Beach - 4526'68”W23050’00”S), São Paulo, Brazil.

Discussion. Nam and Lee (2005) summarized the history of the genus Rhizothrix and provided an identification key for the species known until then (Nam and Lee, 2009). The specimens found in São Sebastiāo Channel do not fit into any of the species extant in the key. It can be identified as Rhizothrix sejongi Nam \& Lee, 2005 following Wells (2007), but when compared to the drawings of the oriental Rhizothrix (Nam and Lee, 2005) it shows differences and is therefore described here as new. It differs from its congener in Korea because P1 endopod 2 has 3 setae and the $R$. sejongi has two: the whole body is covered by "small denticles" in $R$. sejongi, whereas $R$. virginiae seems to be covered by minute setules or spinules and the posterior margin of the 

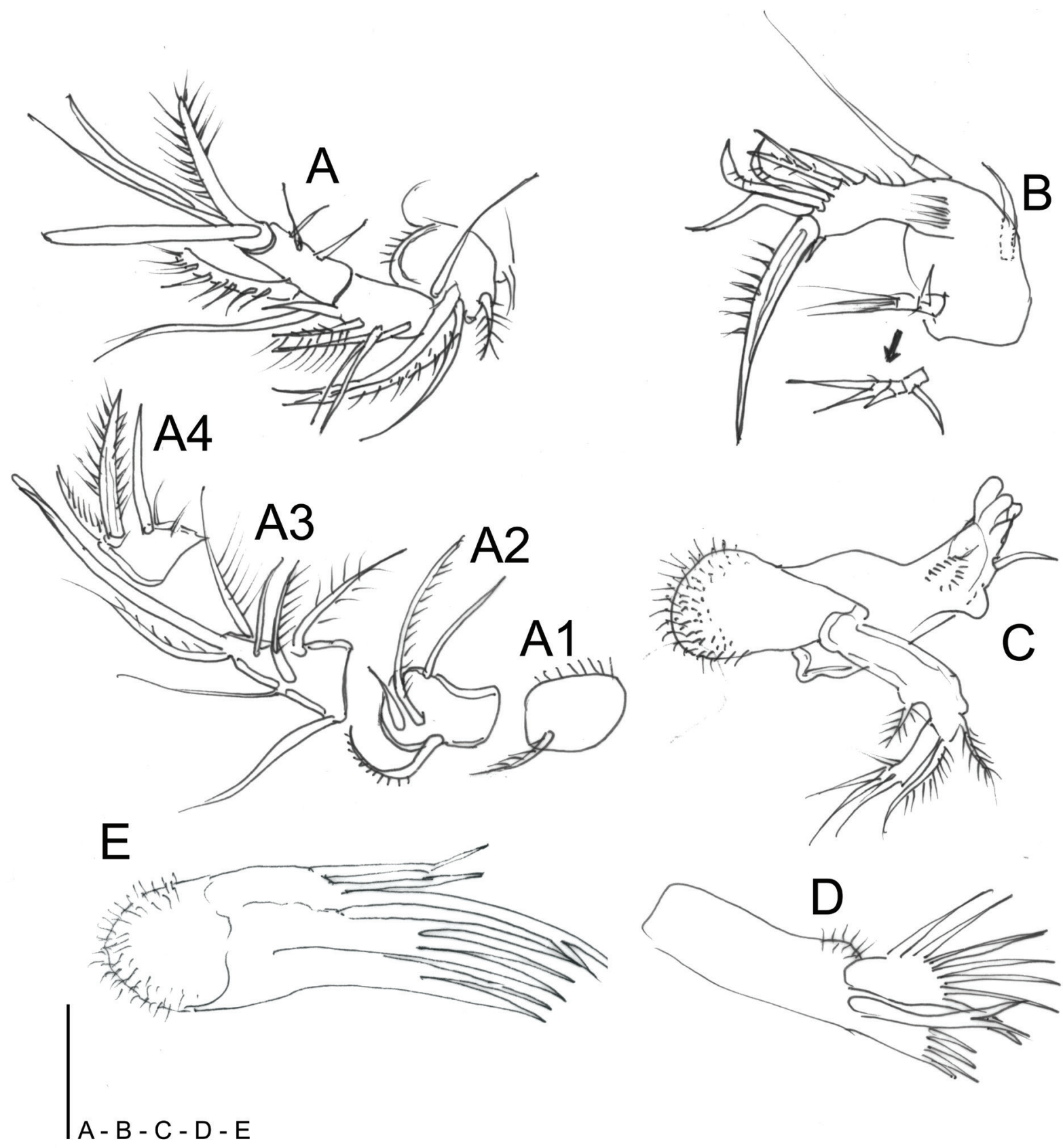

Figure 2. Rhizothrix virginiae n. sp. Female: (A) antennule; A1 - A4 proximal to distal segments of antennules; (B) antenna; (C) mandible; (D) maxillule; (E) maxilla. Scale bars $=0.10 \mathrm{~mm}$; scale bars of appendages $=50 \mu \mathrm{m}$

somites bears a fringe of spinules ventrally and dorsally, limiting one somite from the next. In $R$. sejongi these margins are ornamented by minute spinules. According to Nam and Lee's key the Brazilian specimens are identified as $R$. tenellus Wilson 1932. This species and São Sebastiano specimens are the only Rhizothrix with 3 terminal setae on the second endopod segment of P1. This genus was first described with the name of Quintanus tenellus by Wilson (1932) based on 25 specimens collected in Buzzards Bay bathing beach at Woods Hole,
U.S.A. Our specimens, though also with an elongate body, differ from tenellus in the colour. It is dark and opaque, tenellus is transparent. Our species has P3 and P4 endopods with three well-developed pinnate setae. In the U.S. specimens the P3 second endopod segment has 2 equally long pinnate setae and $\mathrm{P} 4$ second endopod segment has 2 stout spines and 2 short setae. These differences sufficiently support the establishment of a new species for the São Sebastião specimens. 


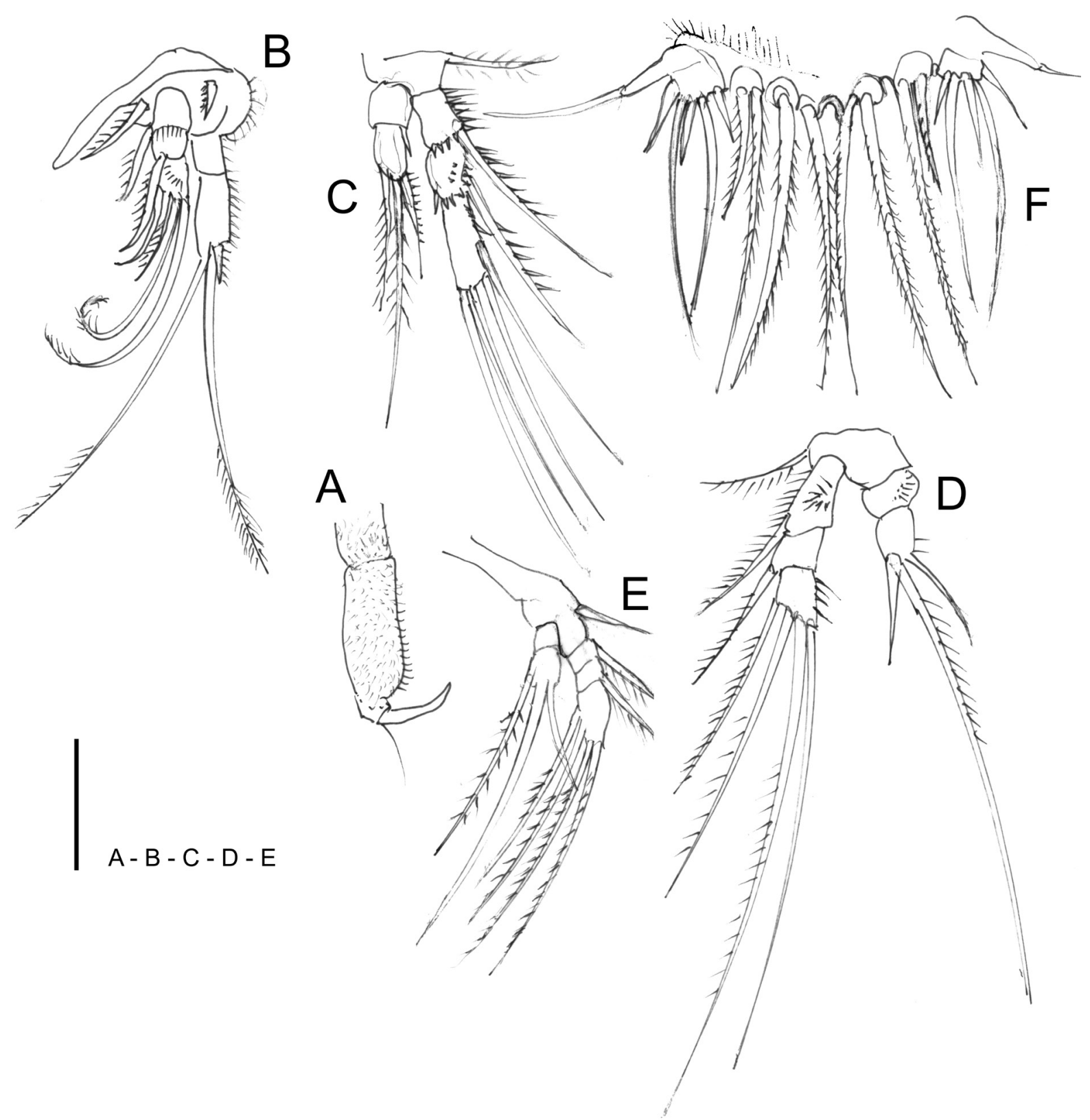

Figure 3. Rhizothrix virginiae n. sp. (A) - maxilliped; (B) P1; (C) P2; (D) P3; (E) P4; (F) P5 right and left. Scale bars = 0.10 mm; scale bars of appendages $=50 \mu \mathrm{m}$

\section{Family Laophontidae Scott, 1905 Genus Galapalaophonte Mielke 1981 Galapalaophonte alvaroi n. sp.}

(Figs. $4-8$ )

Type material. A male (holotype) (MZUSP 30281) and a female (allotype) (MZUSP 30281) collected in Itaçucê, Barequeçaba Bay (São Sebastião, São Paulo,

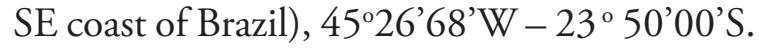

Description. Female: (Fig. 4A, 4B, 4C) Body cylindrical without clear demarcation between prosome and urosome, tapering slightly towards anal segment, surface of dorsal shield irregularly pitted and with rows of minute setules. Length: $0.646 \mathrm{~mm}$ from tip of rostrum to end of caudal rami. Posterior margins of cephalic shield with a minute, lateral pointed projection on each side (Fig. 4C). First pedigerous somite partially fused to cephalon; next four somites not very clearly delimited by rows of spinules/setules. Female dorsally ornamented with pits and posterior somite margins with rows of spinules. Double 




Figure 4. Galapalaophonte alvaroi n. sp. Female: (A) habitus, ventral; (B) habitus, lateral; (C) habitus, dorsal ; (D) genital structure; (E) third leg; (F) fourth leg. Scale bars $=0.10 \mathrm{~mm}$; scale bars of appendages $=50 \mu \mathrm{m}$ 


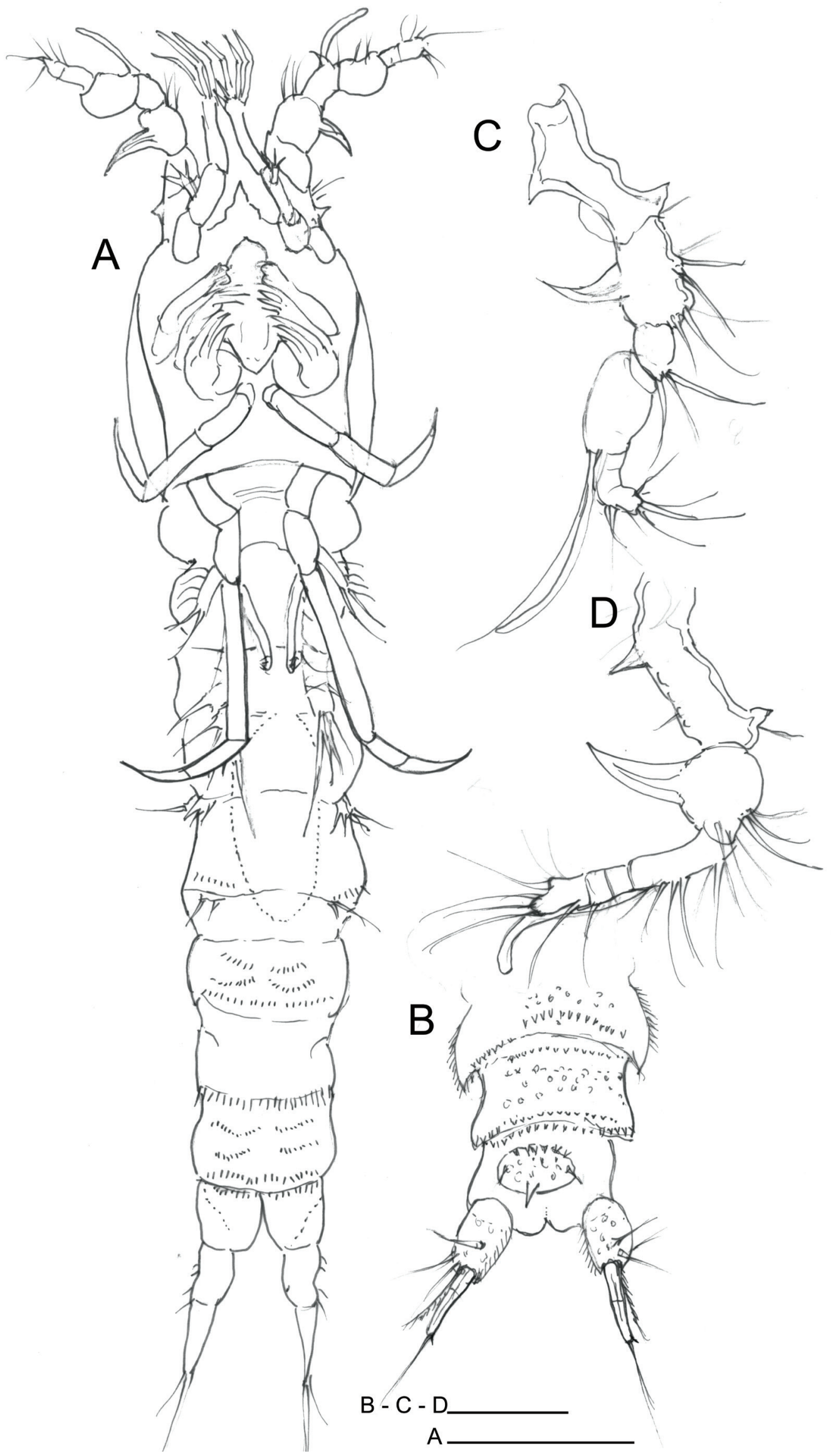

Figure 5. Galapalaophonte alvaroi n. sp. (A) Male, habitus ventral; (B) part of dorsal urosome, showing operculum and furca; (C) male antennule; (D) female antennule. Scale bars $=0.10 \mathrm{~mm}$; scale bars of appendages $=50 \mu \mathrm{m}$ 


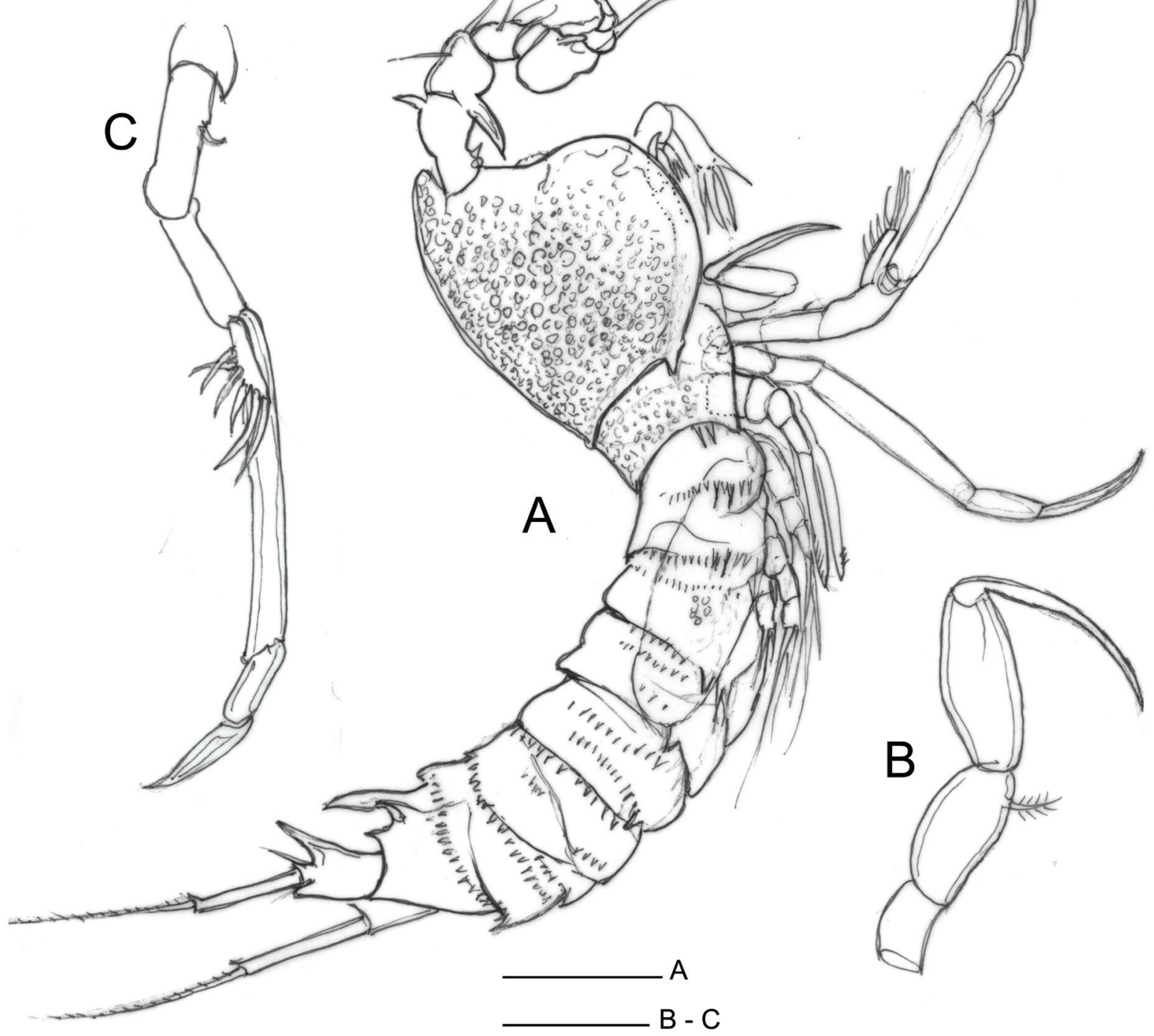

Figure 6. Galapalaophonte alvaroi n. sp. Male: (A) habitus lateral; (B) maxilliped; (C) P1. Scale bars = $0.10 \mathrm{~mm}$; scale bars of appendages $=50 \mu \mathrm{m}$

genital somite: dorsal partial division indicated by row of spinules. Urosomites with lateral projections densely covered by setules; anal operculum (Fig. 4B) with marginal posterior dorsal strong pointed projection, and, laterally a minute sensillum. Caudal rami longer than wide. Seta V of caudal ramus, long, pinnate, mounted on a pedestal with posterior dorsal margin turned up dorsally and pointed. Rows of setules around larger caudal setae. Remaining 4 setae of caudal ramus smaller. Antennule (Fig. 5D) six-segmented, claw-like projection on second segment, 2 small pointed projections on first segment. Setal formula: 0:2:6:7:0:1:5. Antenna (Fig. 7A) with small one-segmented exopod bearing 3 setae, twosegmented endopod with 4 distal setae (3 geniculate) and 3 spines. Mandible (Fig. 7B) strong, gnathobasis armed with three blunt teeth, and marginal tuft of setules, palp with 4 setae. Maxillule (Fig. 7C) with precoxal arthrite bearing terminally a strong and 3 smaller hooks, also small spinules, exopod and endopod one-segmented bearing 2 setae each. Maxilla (Fig. 7D) with 2 endites and basis with long claw; exopod and endopod represented by a marginal seta each. Maxilliped (Fig. 6B) prehensile, with a seta on first and a long terminal claw on second segment. P1 (Fig. 6C) with minute exopod bearing 6 setae and a very 


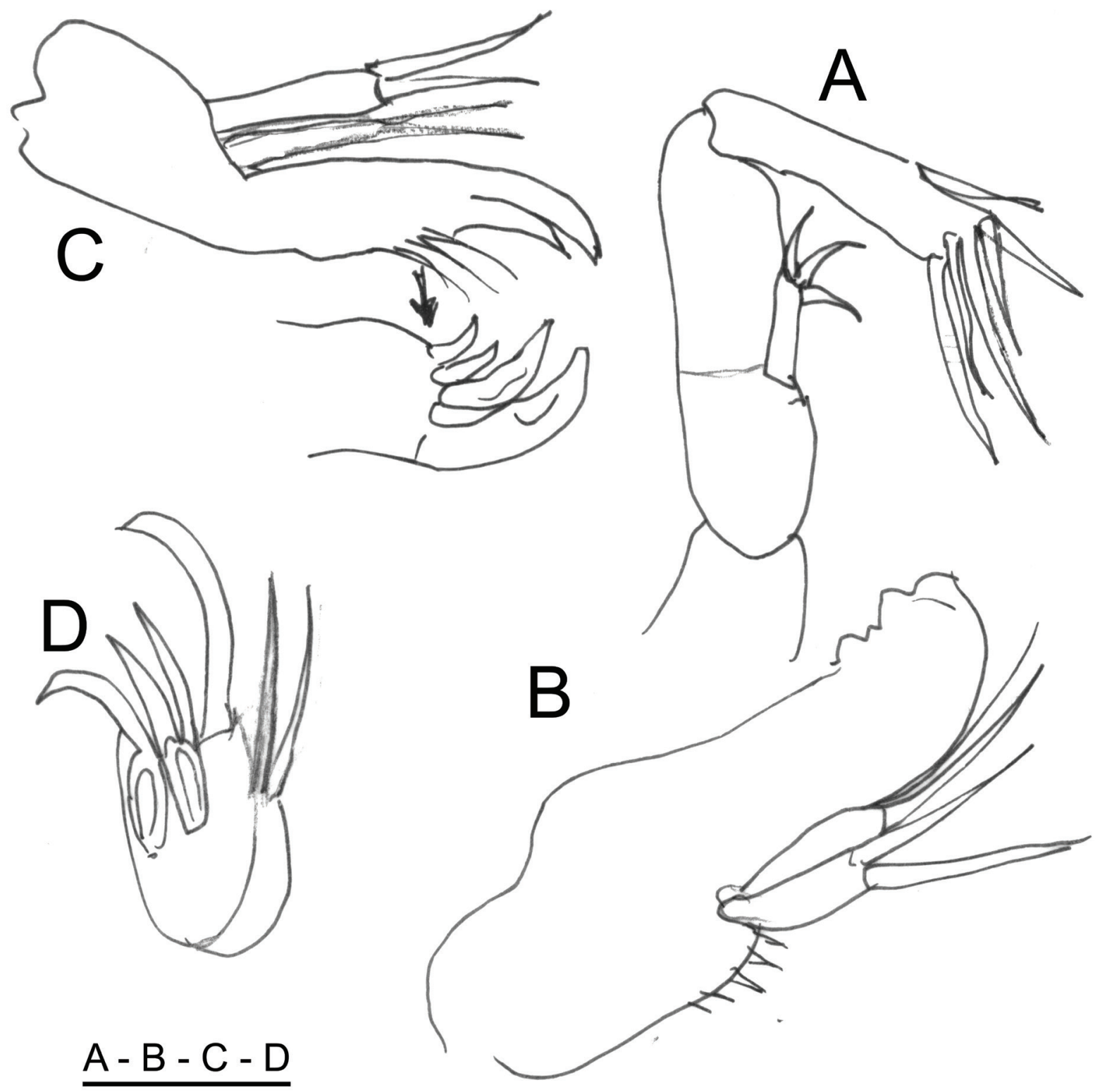

Figure 7. Galapalaophonte alvaroi n. sp. (A) antenna; (B) mandible; (C) maxillule; (D) maxilla. Scale bars = $0.10 \mathrm{~mm}$; scale bars of appendages $=50 \mu \mathrm{m}$

long endopod extending down to the genital segment and ending in a claw-like spine. P2 - P4 with outer articulate seta and segments of rami marginally setulous, as well as basis and coxa. P2 (Fig. 8D, E) endopod twosegmented with 2 setae; exopod represented by 2 digitiform setae or one digitiform and another simple minute seta. P3 (Fig. 4E): exopod three-segmented with a bipinnate seta on first and second segments and 3 setae on third, innermost longest pinnate, the middle one thick and a lateral very thin small seta; endopod two-segmented with three distal setae. P4 (Fig. 4F): exopod three-segmented, first and second segments with one strongly bipinnate seta each and four terminal setae on distal segment: outer one very thin and small, second thin brush-like, third very long pinnate, fourth half as long. Endopod onesegmented bearing long bipinnate seta. P5 (Fig. 8H) baseoendopod with 2 long, 3 short setae and marginal row of setules, also outer seta; exopod with 5 setae ( 4 bipinnate).

Male: Body (Fig. 5A, 6A) similar in shape to female's, $0.480 \mathrm{~mm}$ long. Rostrum small, pointed. Margins of somites with minute 


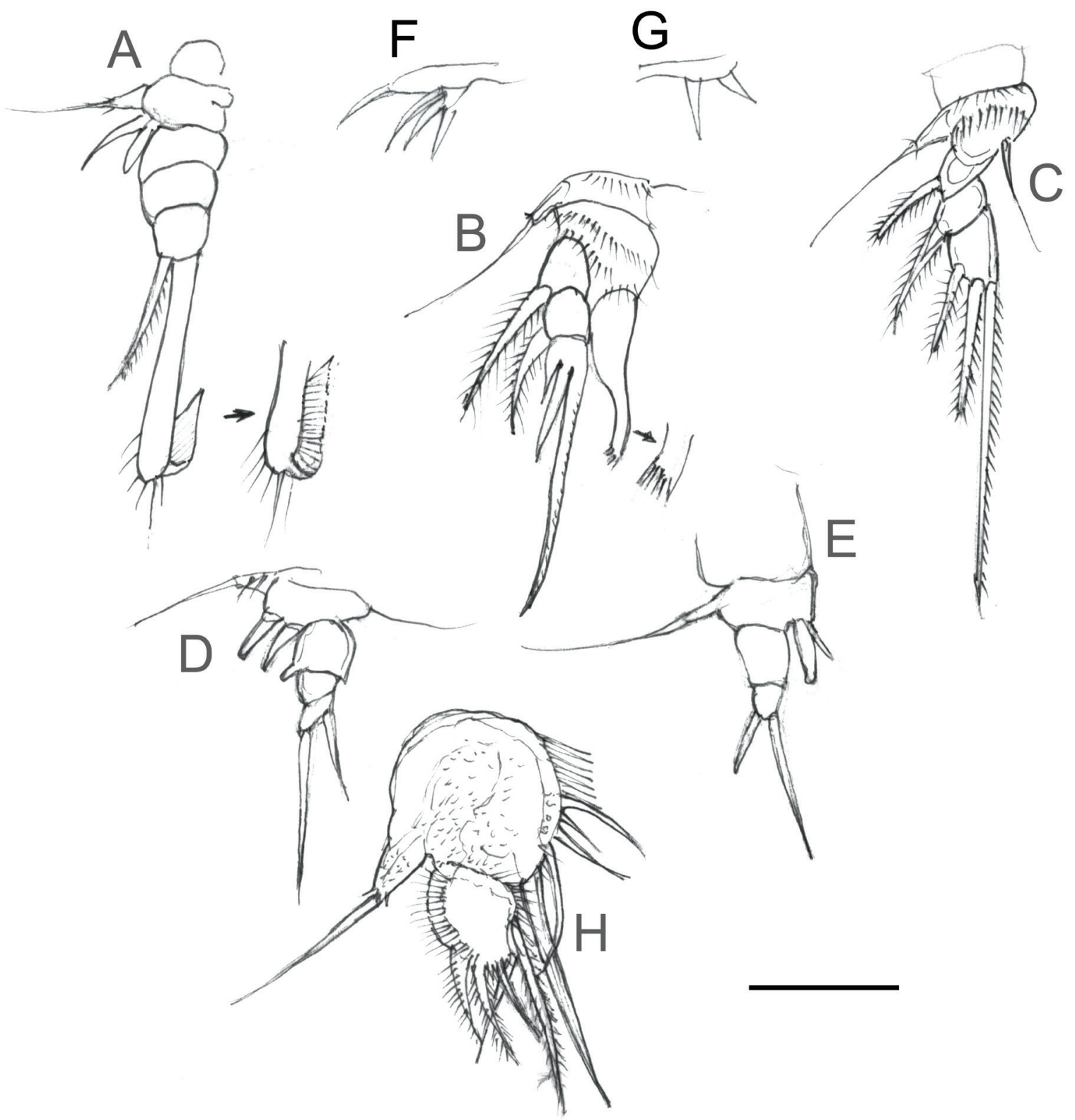

Figure 8. Galapalaophonte alvaroi n. sp. (A) male P2; (B) male P3; (C) male P4; (D) female left P2; (E) female right P2 of another specimen; (F) male P5; (G) male P6; (H) Female P5. Scale bars $=0.10 \mathrm{~mm}$; scale bars of appendages $=50 \mu \mathrm{m}$

spinules, laterally spines and rows of setules. Anal somite with a spine-like lateral projection on each side of the anal operculum (Fig. 6A), armed with a strong posterior pointed projection. Both caudal rami elongated dorsally into a spine-like projection. Furcal setae: 5 shorter setae, long pinnate seta $\mathrm{V}$ mounted on a pedestal which also ends in a dorsally turned up point (Fig. 6A). P1 long, as in female. P2 shorter than P1 (Fig. 8A), with outer basal seta and two small setae representing exopod; endopod three-segmented with a pinnate long seta and a hyaline tube ornamented distally by a row of transparent setules and a bunch of minute setae forming a comb or brushlike structure. P3: coxa and basis (with rows of setules) separate, three-segmented exopod, with first and second segments bearing a thick pinnate seta each, the third with 3 setae (Fig. 8B); endopod strongly modified seta, bottleshaped, wide near insertion, straightening towards brush-like end. P4 (Fig. 8C) coxa and basis with rows of setules, basis bearing outer seta, three-segmented exopod with strongly pinnate setae on first two segments and third with 3 pinnate setae; no endopod (represented 
in one specimen by a very small seta). P5 (Fig. 8F) with outer seta on a narrow basis; exopod one-segmented with 3 setae. P6, (Fig. $8 \mathrm{G}) 2$ setae on posterior margin of somite. Spermatophore large, very dilated.

Etymology. The name given to the new species is in honor of Prof. Dr. Alvaro Migotto to whom I owe the offer to work in the CEBIMar, and to make this work possible.

Type locality. São Sebastião Channel (Itaçucê, Barequeçaba Beach - 45026'68”W - 23050'00"S), gravel bottom, 7 m deep, São Paulo, SE coast of Brazil.

Discussion. Coull and Zo (1980) described Laophontina variabilis and $L$. triarticulata from the Southeastern continental shelf of the U.S.A. Fiers (1991) reviewed the genus Laophontina Norman and Scott, 1905 and reexamined all the type series of the species in addition to analyzing new material from the east African coast and the Caribbean. He redefined the genus Laophontina to include the boreal species and redefined the genus Galapalaophonte Mielke, 1981 comprising the Amphi-American species. The Brazilian specimens here considered belong to the Amphi-American genus, because "the anal segment has dorsolateral sharp extensions, the anal operculum has an upward directed median thorn, "the integument of the thorax is pitted" etc. (see Fiers, 1991, p, 20). Our species does not fit into any of the existing descriptions of the Galapalaophonte species known until now (Coull and Zo, 1980; Mielke, 1981; Fiers, 1991). The Brazilian species is very closely related to $G$. triarticulata and to $G$. pacifica Mielke, 1981. Small differences in setation and in the segmentation of the appendages occur. P1 exopod has 5 setae in $G$. triarticulata, but 6 setae in $G$. alvaroi and in $G$. pacifica. The endopod has 5 setae in $G$. alvaroi; but 4 in $G$. triarticulata and in $G$. pacifica. P2 female $G$. triarticulata and $G$. alvaroi have the exopod represented by two small elements, in $G$. pacifica three. The male P2 differs in the distal ornamentation of the endopod seta in the three species. In G. alvaroi and in G. pacifica the anal operculum spine-like dorsal projection is onepointed, not two-pointed as in G. triarticulata. These differences sufficiently support the establishment of a new species for the São Sebastiāo specimens.

\section{Family Nannopodidae Brady, 1880 \\ Genus Laophontisochra George, 2002 Laophontisochra terueae n. sp.} (Figs. 9-11)

Type material. 1 male holotype (MZUSP 30279) and 2 females (paratypes, badly preserved). Preserved in formaldehyde $4 \%$, cleared in lactic acid, mounted in glycerine, now transferred to etanol 50\% (CEBIMar copepod collection \# 10)

Description. Male: Body long, cylindrical, slightly flattened dorsoventrally (Fig. 9C), covered by a thin layer of minute setules, to which a mucous frill adheres. Length from point of rostrum to end of furcal rami: male $0.642 \mathrm{~mm}$. Rostrum (Fig. 10A) large, triangular, defined, with two thin anterior sensilla. Dorsally the body is striated longitudinally (Fig. 10A). Furcal rami are three times longer than wide with lateral mucous frill adhered to the minute transparent setules (Fig. 9A). Antennule (Fig.10D) foursegmented: first segment covered by minute setules and with a little thumb-like proximal process; second segment with 4 setae; third with 7 setae and a protuberance with an aesthetask and two long setae; last with 5 or 7 setae and an aesthetask. Antenna (Fig. 9E) with an allobasis and one-segmented endopod with spines (two marginal, one terminal), lateral setules, 3 terminal geniculate and a non-geniculated setae. Mandible (Fig. 10E): a three-teethed gnathobasis and a palp bearing 2 lateral marginal setae, an endopod with two distal small curved setae, a longer seta (exopod) and a lateral preterminal process. Maxillule (Fig. 10F) with arthrite bearing 3 terminal spines, thin long endite with two terminal setae, exopod with seven pointed setae. Maxilla (Fig. 10G): basis prolonged forming long claw terminally bifid; round protuberance with 


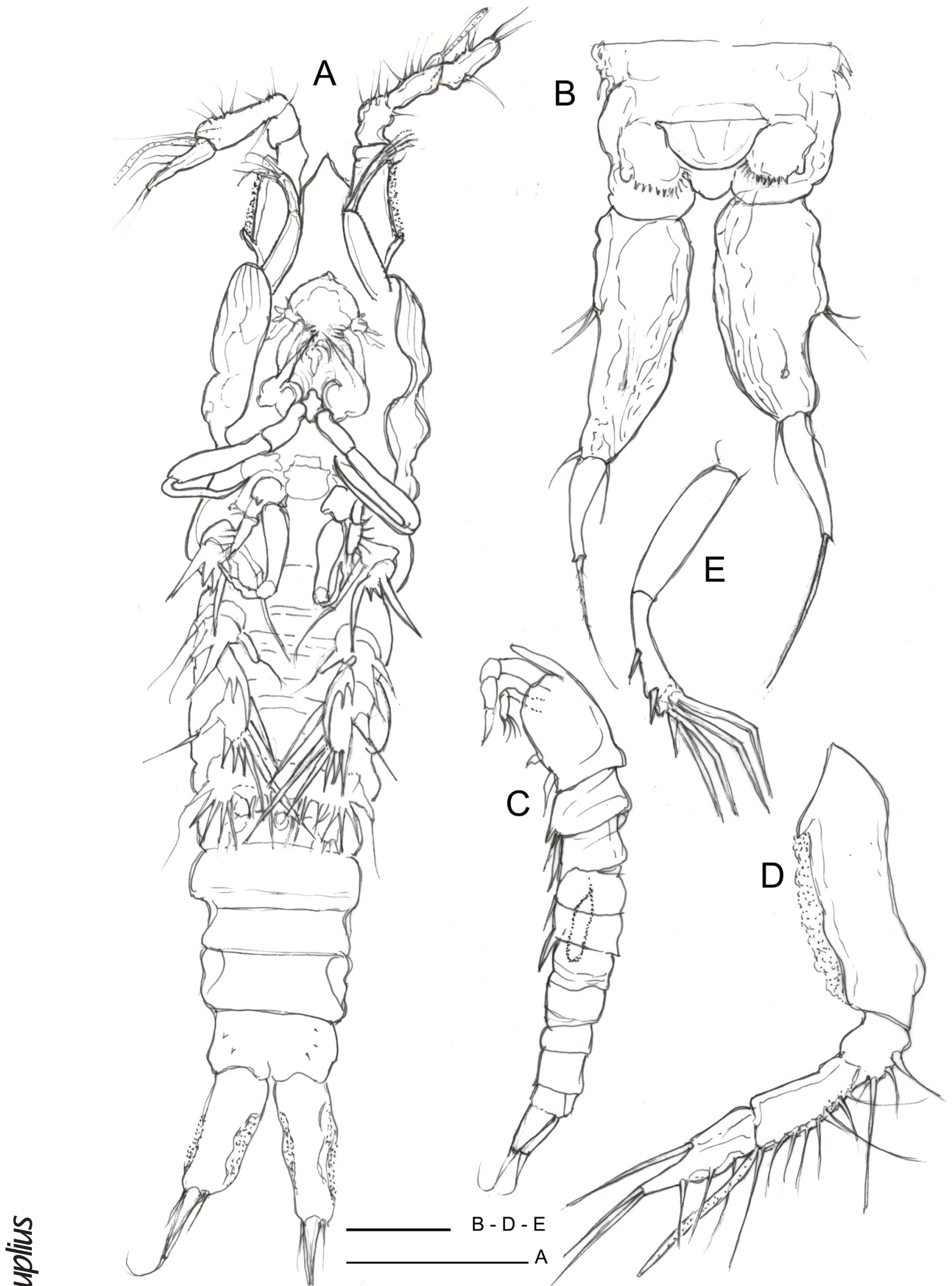

Figure 9. Laophontisochra terueae n. sp. Female: (A) Habitus, ventral; (B) anal somite and furcal rami; (C) Male, habitus lateral (schematic); (D) female antennule; (E) antennal endopod. Scale bars $=0.10 \mathrm{~mm}$; scale bars of appendages $=50 \mu \mathrm{m}$ 


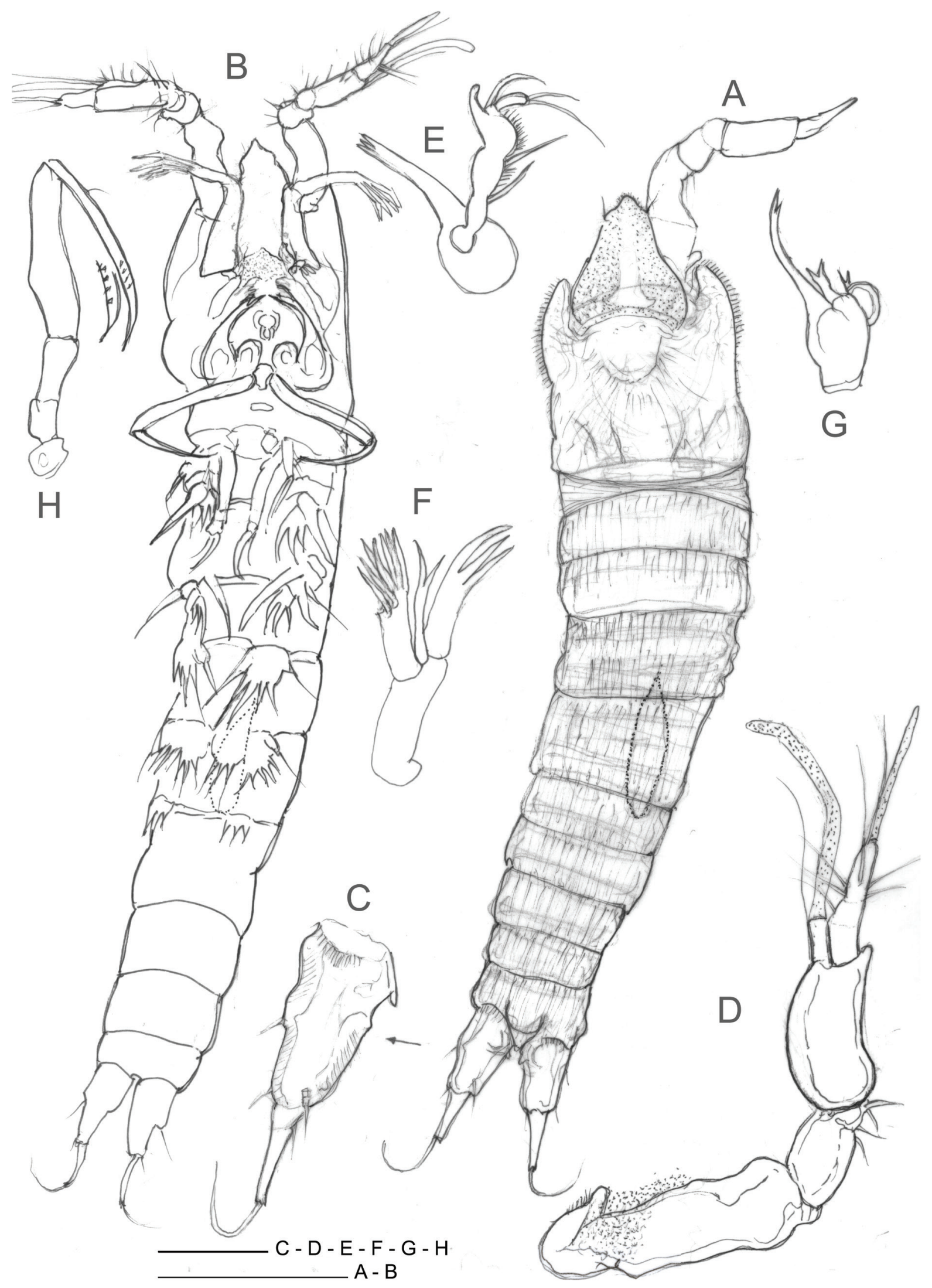

Figure 10. Laophontisochra terueae n. sp. (A) male habitus dorsal; (B) male habitus ventral; (C) male furcal ramus; (D) male antennule; (E) mandible; $(F)$ maxillule; $(\mathrm{G})$ maxilla; $(\mathrm{H})$ maxilliped. Scale bars $=0.10 \mathrm{~mm}$; scale bars of appendages $=50 \mu \mathrm{m}$ 


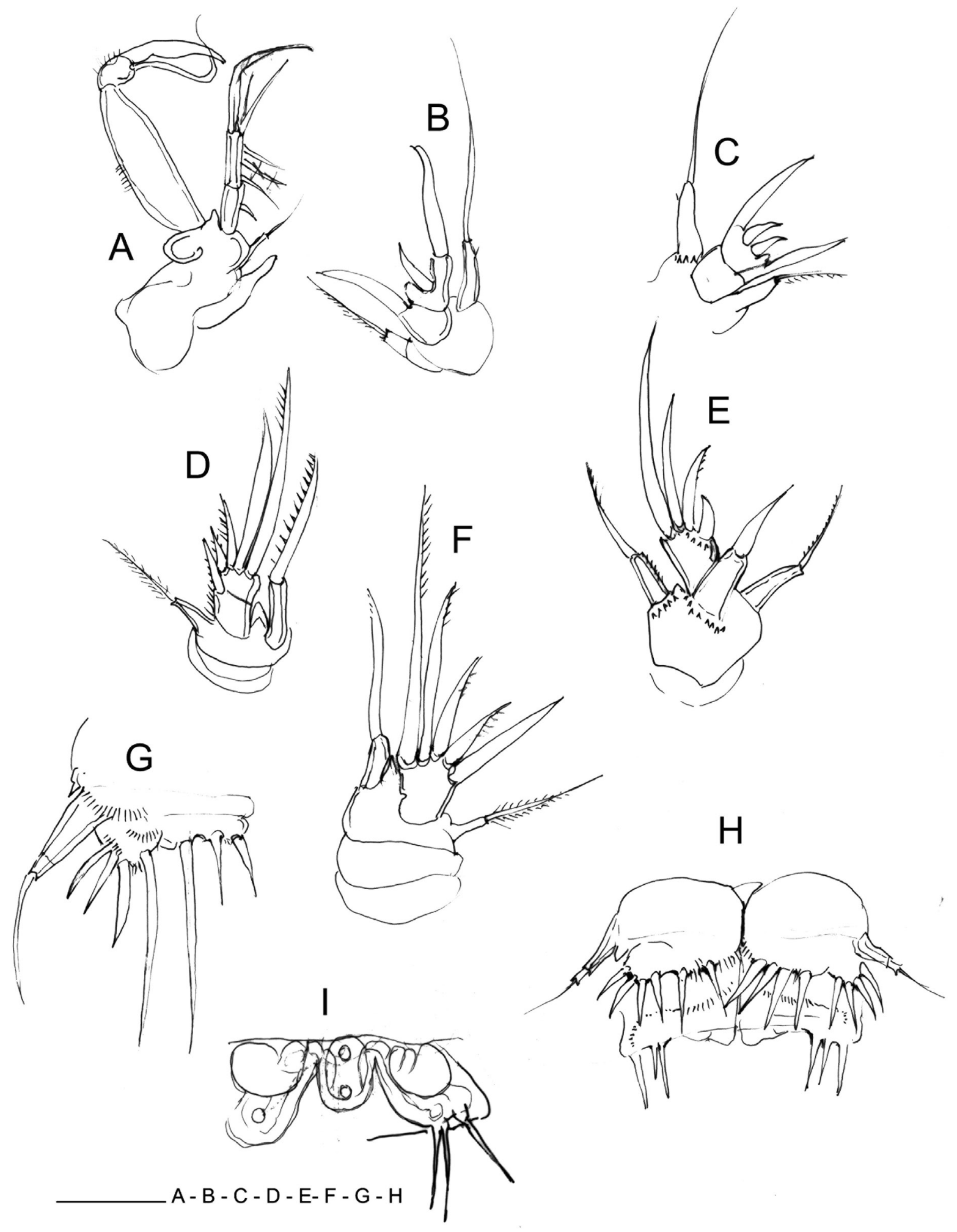

Figure 11. Laophontisochra terueae n. sp. (A) first leg; (B) second leg (left); (C) second leg (right); (D) third leg; (E) fourth leg (female); (F) fourth leg (male); (G) Fifth leg (female); (H) Male fifth legs and sixth legs; (I) Female sixth legs and genital structures. Scale bars $=0.10 \mathrm{~mm}$; scale bars of appendages $=50 \mu \mathrm{m}$ 
small anterior process (endite) and an endite terminally bifid. Maxilliped (Fig. 10H) well developed, prehensile, with coxa, basis, long endopod and terminal claw with preterminal marginal denticles and small proximal seta. Pereiopods (Fig. 11) reduced; most of the seta/ spines with marginal very transparent spinules. P1 (Fig. 11A) with both rami 2-segmented, coxa protuberant externally without cristae or acute points, basis with outer seta, exopod bearing 1 seta on first segment, 1 lateral and 3 terminal setae on second segment also setulous marginally; endopod with first segment twice wider than exopod and about twice longer, second segment very short, with preterminal tuft of setules and 2 terminal setae (thicker one claw-like, the other one longer, thinner and curved). P2 (Fig. 11B-C) small with basal bipinnate outer seta, exopod two-segmented: first segment with one strong seta (spine), second with 2 or 3 (compare P2 right - Fig. $11 \mathrm{~B}$ - with P2 left - Fig. 11C) in the same animal (a variation), innermost seta longer than the others; endopod one-segmented with long strong seta; rows of spinules occur around insertion basis of rami and of spines. P3 (Fig. 11D): also reduced with outer seta on basis, exopod two-segmented with strong seta or spine on first segment and 4 setae or spines on second increasing in length from the outside to the inside, small triangular basal process separates exopod from one-segmented endopod with strong long seta or spine. P4 (Fig. 11F): with outer bipinnate seta; both rami one-segmented and separated basally by a small triangular protuberance. $\mathrm{P} 4$ exopod with a strong pinnate seta on inner margin and 4 pinnate terminal setae or spines increasingly longer; endopod with a long terminal seta or spine. P5 (Fig. 11H) with row of marginal setules and coalesced baseoendopod and exopod: setophore with outer seta, exopod bearing 4 setae or spines and endopod with 2 or 4 setae or spines, all bipinnate. P6 (Fig. $11 \mathrm{H}): 3$ setae or spines on ventral margin of next somite.

Female: Body (Fig. 9A) as in the male (0.571 and $0.482 \mathrm{~mm}$ long). Antennule: slightly thinner third segment, compared to male's antennule. Mouth appendages partly damaged. Maxilla and maxilliped like male's. Female first leg, second and third legs like male's. Fourth leg (Fig. 11E) exopod is two-segmented, instead of one-segmented as in male. P5 (Fig. 11G) with coalesced baseoendopod and exopod. The 4th seta of the exopod and the first seta of the endopod, longer than the other setae. P6 is part of the genital complex of the female, composed of three lateral marginal setae which over the genital somite (Fig. 11).

Etymology. The name of the species is in honour of a dear friend and research colaborator, Terue Cristina Kihara.

Type locality. Parcel da Praia Grande, São Sebastiāo Channel (23049'02"S 4524'19”W), São Paulo, Brazil.

Discussion. George (2002) described Laophontisochra maryamae and another specimen from the Magellan region under the name Laophontisochra sp. This species was redescribed by Huys and Kihara (2010) and transferred to a new genus Acuticoxa together with another specimen found off the Brazilian coast in the Ubatuba region near to São Sebastião. The specimens collected in São Sebastiâo Channel belong to the genus Laophontisochra because they do not exhibit acute spine-like processes on the coxae of the P1 as the genus Acuticoxa and they fit the amended diagnosis of the genus Laophontisochra by Huys and Kihara (2010), except in reference to the description of the second and third legs. These have no endopods in L. maryamae but exhibit endopods in L. terueae. The male, now described for the first time, shows very little differences in relation to the female. The male P5 baseoendopod has 2 spines on the right and 4 spines on the left; the female has 3 spines. In the female P5 setae diverge in length; in the male they are all short. The male body is thinner than the female's.

Differences between $L$. terueae and $L$. maryamae: The maxilliped is proportionally larger in L. terueae than in L. maryamae; P1 in L. terueae has a wider basis than in L. maryamae 
and a smooth basal outline. Endopod is missing in $\mathrm{P} 2$ and $\mathrm{P} 3$ of L. maryamae and present in P2 to $\mathrm{P} 4$ of $L$. terueae. $\mathrm{P} 5$ is much reduced in $L$. maryamae while in $L$. terueae it has a full set of endopod spines besides the exopod with 4 setae or spines. The P5 of $L$. terueae resembles that of Acuticoxa much more than that of Laophontisochra maryamae George.

\section{REFERENCES}

Alonso, M. 1996. Crustacea, Branchiopoda. p. 1-486. Àlvarez, R.M.F. 1986. Estudo dos copépodos Harpacticoida marinhos do Estado de Sáo Paulo. In: Mini-Simpósio de Biologia Marinha, 5. Resumos, São Sebastião, CEBIMar/USP, p. 4.

Björnberg, T. and Kihara, T.C. 2013. On Tetragonicipitidae (Crustacea, Copepoda) from the Channel of São Sebastião, Brazil, with description of their nauplii and two new species of Phyllopodopsyllus. Zootaxa, 3718: 501-529,

Coull, B.C. and Zo, Z. 1980. Revision of Laophontina (Copepoda: Harpacticoida), including three new species and a key. Transactions of the American Microscopical Society, 99(1): 30-43.

Fiers, F. 1991. A revision of the genus Laophontina Norman \& Scott (Copepoda, Harpacticoida). Bulletin van het Koninklijk Belgisch Instituut voor Natuurwetenshappen, Biologie, 61: 5-54.

George, K.H. 2002. New phylogenetic aspects of the Cristacoxidae Huys (Copepoda, Harpacticoida), including the description of a new genus from the Magellan region. Vie et Milieu, 52(1): 31-41.

Huys, R. and Kihara, T.C. 2010. Systematics and phylogeny of Cristacoxidae (Copepoda, Harpacticoida): a review. Zootaxa, 2568: 1- 38.

Kihara, T.C. 2003. Diversidade dos copépodes harpacticóides da meiofauna marinha do litoral Norte do Estado de São Paulo. Universidade de São Paulo - USP, Instituto de Biociências, São Paulo, Brazil, Ph.D. Thesis. 214p. [Unpublished].

Mielke, W. 1981. Interstitielle Fauna von Galapagos. XXVIII. Laophontinae (Laophontidae), Ancorabolidae (Harpacticoida). Mikrofauna des Meeresbodens, 84: 1-104.

Nam, J.N. and Lee, W. 2005. A new species of the genus Rhizothrix (Copepoda, Harpacticoida; Rhizothricidae) from Korean waters. Proceedings of the Zoological Society of Washington, 118(4): 692705.

Nam, J.N. and Lee, W. 2009. On the first swimming leg of Rhizothrix sejongi Nam \& Lee, 2005 (Copepoda, Harpacticoida: Rhizothricidae), with an amended key to species of the genus Rhizothrix. Proceedings of the Biological Society of Washington, 122(2): 212214.

Wells, J.B.J. 2007. An annotated check list and keys to the species of Copepoda Harpacticoida (Crustacea). Zootaxa, 156: 1-872.

Wilson, C.B. 1932. The Copepods of Woods Hole Region Massachusetts. Smithsonian Institution U.S. National Museum Bulletin, 158:1-625 + plates/figs.

Submitted 25 April 2014 Accepted 15 September 2014 